\title{
THE EFFECT OF THE LARGE-SCALE INTRODUCTION OF SIGNAL CRAYFISH ON THE SPREAD OF CRAYFISH PLAGUE IN SWEDEN
}

\author{
P. BOHMAN (1), F. NORDWALL (2), L. EDSMAN (1)
}

(1) Swedish Board of Fisheries, Institute of Freshwater Research, SE-17893 Drottningholm, Sweden.

E-Mail: patrik.bohman@fiskeriverket.se, lennart.edsman@fiskeriverket.se

(2) Swedish Board of Fisheries, Dep. of Management of Resources, Box 423, SE-401 26 Göteborg, Sweden.

E-Mail: fredrik.nordwall@fiskeriverket.se

Reçu le 31 mai 2005

Accepté le 23 janvier 2006

Received May 31, 2005

Accepted January 23, 2006

\begin{abstract}
Since 1907, coinciding with the arrival of the crayfish plague, the noble crayfish (Astacus astacus) has steadily declined in Sweden. To substitute the noble crayfish fishery lost, mainly due to the plague, and since the species is highly susceptible to the disease, the Swedish government started a large-scale introduction of the American signal crayfish (Pacifastacus leniusculus) in the end of the 1960's. The signal crayfish is a chronic carrier of crayfish plague (Aphanomyces astaci), and it is likely that the introduction of this species has had an effect on the spread of the disease to the remaining noble crayfish populations. 6,961 crayfish plague outbreaks were recorded between the years 1907-2004. 65\% of the recorded outbreaks (4,531 records) occurred after 1969. The legislation for giving licenses to stock signal crayfish has gone from being restrictive in the end of the 1960's, to becoming quite liberal in the 1980's, and to becoming more restrictive again starting in 1994. From 1983-1994 the number of licenses increased with over 500\% (from 536 to 3,000 ). This coincides with the largest number of recorded crayfish plague outbreaks ever. To assess the relationship between the large-scale introduction of signal crayfish, the spread of crayfish plague, and the steady decline of noble crayfish populations in Swedish waters, we compared the number of outbreaks between two 20-year periods, before and after the introduction of the signal crayfish. We found that the introduction of the signal crayfish, due to a more permissible legislation, have accelerated the spread of crayfish plague to noble crayfish populations in the country, and that is the main reason for the current decline of native crayfish populations.
\end{abstract}

Key-words: Pacifastacus leniusculus, Astacus astacus, crayfish plague, Aphanomyces astaci, large-scale introduction, fisheries legislation, database.

\section{IMPACT DE L'INTRODUCTION À GRANDE ÉCHELLE DE L'ÉCREVISSE SIGNAL SUR LA PROPAGATION DE LA PESTE DES ÉCREVISSES EN SUĖDE}

\section{RÉSUMÉ}

Depuis 1907, Les populations d'écrevisse noble (Astacus astacus) ont connu un déclin régulier en Suède, coïncidant avec l'arrivée de la peste des écrevisses. Afin 
de compenser la baisse de revenu tiré de l'exploitation de l'écrevisse noble, baisse principalement due à la peste à laquelle cette espèce d'écrevisse est particulièrement sensible, le gouvernement suédois a commencé à introduire à grande échelle l'écrevisse signal américaine (Pacifastacus leniusculus) vers la fin des années 60. L'écrevisse signal est porteur chronique de la peste des écrevisses (Aphanomyces astaci) et il est probable que l'introduction de cette espèce a eu un impact sur la propagation de la peste vers les populations d'écrevisses nobles en place. 6961 cas de peste des écrevisses ont été enregistrés entre 1907 et 2004. 65\% des cas enregistrés (4 531 cas) sont postérieurs à 1969. La législation sur les repeuplements en écrevisse signal a évolué depuis les années 60 , où elle était plutôt restrictive, vers les années 80 , où elle est devenue assez libérale, pour devenir à nouveau plus restrictive à partir de 1994. De 1993 à 1994, le nombre de permis de repeuplement a crû de 500\% (de 536 à 3 000). Cela coïncide avec le plus grand nombre de cas de peste des écrevisses jamais enregistré. Pour établir le lien entre l'introduction à grande échelle de l'écrevisse signal, la propagation de la peste de l'écrevisse, et le déclin régulier des populations de l'écrevisse noble dans les eaux suédoises, nous avons comparé le nombre de cas de peste enregistrés pendant deux périodes de 20 ans, avant et apès l'introduction de l'écrevisse signal. Nous avons trouvé que l'introduction de l'écrevisse signal, résultant d'une législation plus permissive, a accéléré la propagation de la peste de l'écrevisse parmi les populations d'écrevisse noble dans le pays, et que c'est la raison principale du déclin des populations natives d'écrevisses.

Mots-clés: Pacifastacus leniusculus, Astacus astacus, peste des écrevisses, Aphanomyces astaci, introduction à grande échelle, législation des pêches, base de données.

\section{INTRODUCTION}

The noble crayfish (Astacus astacus) is the only indigenous crayfish species in Sweden (SKURDAL et al., 1999). Since 1907, when the crayfish plague first occurred in the country (ARWIDSSON, 1920; ALM, 1929), there has been a steady decline of noble crayfish populations in Swedish waters (FISKERIVERKET and NATURVÅRDSVERKET, 1998). In 1900 the number of locations with noble crayfish was estimated to 30,000 (FISKERIVERKET, 1993; FISKERIVERKET and NATURVÅRDSVERKET, 1998). During the following years their number severely decreased. In 1960 only $50 \%$ of the original populations were left (UNESTAM, 1969). In 1994 the populations reached 1,724 (FISKERIVERKET and NATURVÅRDSVERKET, 1998), and in 1997 there were 1,597 remaining noble crayfish populations (FISKERIVERKET and NATURVÅRDSVERKET, 1998). In 2002, there were about 1,000 populations (DATABASE OF CRAYFISH OCCURRENCES, 2005) - only 3\% compared to the number of populations in 1900.

Laboratory and field studies have shown that all individuals of the noble crayfish die after exposure to crayfish plague (Aphanomyces astaci) (UNESTAM, 1969; ALDERMAN and POLGLASE, 1988; EVANS and EDGERTON, 2002). Every outbreak of crayfish plague in a population of noble crayfish can, thus, be regarded as a noble crayfish population lost. Crayfish plague has been proposed as the major cause of the decline in native European crayfish species (ALDERMAN, 1996) and noble crayfish in Sweden (EDSMAN, 2000).

Due to the decline, and to the fact that the Swedish market for freshwater crayfish is highly attractive, the Swedish government initiated a test introduction of the American signal crayfish (Pacifastacus leniusculus) into lake Träsksjön in 1960 (SVÄRDSON, 1965), followed by introductions into a few other lakes. It was then assumed that the signal crayfish would fill the ecological niche once held by the noble crayfish, since the signal crayfish was thought to resemble the noble crayfish in both morphology and ecology 
(FJÄLLING and FÜRST, 1985). Some populations were established, and based on these results a large-scale introduction of the signal crayfish was launched into 64 lakes in 1969. The large-scale introduction of signal crayfish ended in 1994.

The signal crayfish is a chronic carrier of crayfish plague (UNESTAM, 1972; DIEGUEZ-URIBEONDO, et al., 1997; SÖDERHÄLL and CERENIUS, 1999). Consequently, it is likely that these introductions have had an impact on the spread of the disease to the remaining noble crayfish populations.

In order to protect wild stocks and prevent spreading of fish diseases, a license for stocking of fish, including crayfish, has been prescribed in the Swedish fisheries legislation since 1954. The changes in fisheries legislation reflect the policy of the Swedish authorities regarding introductions of signal crayfish. The legislation for issuing licenses to introduce signal crayfish into Swedish waters has varied over the period from 1969 to 2004 . A more liberal legislation, coupled with a great interest in a productive fishery, evidently results in an accelerating number of signal crayfish populations. With an increasing number of signal crayfish populations in the country, the risk of spreading the crayfish plague to the remaining noble crayfish populations is expected to increase.

Therefore, the aim of the study is to investigate:

(i) the effect of the introduction of signal crayfish on the rate of crayfish plague outbreaks;

(ii) the effect of the signal crayfish on the decline of the noble crayfish population;

(iii) the effect of the legislation on the rate of stocking licenses for signal crayfish.

\section{MATERIALS AND METHODS}

The registered outbreaks of crayfish plague, which this study is based upon, have been taken from the Swedish database of crayfish plague (DATABASE OF CRAYFISH PLAGUE, 2005). The initial registration of waters with crayfish plague outbreaks has been done by each of the 21 Swedish county administrations (regarding the period 1950-2004). These records were then collected, quality rated, and digitalised by the Swedish Board of Fisheries. We also compiled historical data (not previously collected by the county administrations), from the period 1907 to 1949, into the database, and reviewed hundreds of pages of historical literature covering plague outbreaks (see REFERENCES). There may be a problem with using historical data in that the effort to gather, and the possibilities to document, information, were smaller going back almost a hundred years. In this case, the large commercial interest in crayfish, however, meant that the documentation was done thoroughly, even in the first half of the $19^{\text {th }}$ century. The historical data were taken from carefully compiled yearly reports on the spread of crayfish plague in Sweden, printed in the Swedish Journal of Fishery (Svensk Fiskeritidskrift). In addition, the historical data, and the data collected by the county administrations, were cross-referenced with other literature (e.g. ALM, 1929), people at the Swedish county administrations, and maps, in order to correct and check the quality of the data. We also worked closely with the county administrations to gather information on crayfish plague not previously reported to the Swedish Board of Fisheries. It is important to point out that the database only includes records where the waters were considered plague infested. Waters that have had noble crayfish declines due to other sources (not plague) are out ruled.

We compiled the registered number of outbreaks, and visualised them as a timeline chart for the period 1907-2004. This is the first time that the number of crayfish plague outbreaks, over time, has been reconstructed for such a long time period in Sweden. The timeline chart was divided into 5-year periods, since this resolution was best suited 
for a visual examination of the chart. It also facilitates the ocular inspection for changes within the chart. By constructing thematical maps, we could visually investigate a refined geographical resolution within the chart, as each map represents the number of plague outbreaks in every county in Sweden, for a specific 5-year period.

We, then, made a comparison that indicated whether the introduction of signal crayfish has had any effect on the plague outbreaks (e.g. increased their numbers). Since we knew the starting point for the large-scale introduction of signal crayfish (1969), we chose two 20-year periods (period I = 1940-60; period II = 1975-95), before and after this year, to compare the number of outbreaks for each county in Sweden. The length of these periods was chosen to smooth out yearly variation. 16 out of the 21 counties of Sweden have reported plague outbreaks, and only these counties were included in the analysis. A non-parametric test (Wilcoxon signed rank test) was used to test for differences between the two time periods.

We also compiled and studied the changes in fisheries legislation, concerning licenses to introduce signal crayfish into Swedish waters, during the large-scale introduction (1969-94), and compared the results with ocular investigations of the time chart for crayfish plague out breaks.

\section{RESULTS}

A number of 6,961-recorded plague outbreaks have been registered in Sweden, since the first outbreak of crayfish plague in 1907 (Figure 1). The geographic locations of the outbreaks are concentrated to the Middle East and the southeast regions of Sweden. These regions once held the largest number of noble crayfish populations, and later became the centre regions where most signal crayfish introductions were carried out.

Although, our focus is on the large-scale introduction (1969-94), we present a historical timeline chart of crayfish outbreaks, which shows all the 6961 recorded plague outbreaks from 1907 to 2004 (Figure 2). The chart reveals several periods with large number of outbreaks, but before 1969 the outbreaks seldom exceeds 400 for each 5-year period. $65 \%$ of the recorded outbreaks (4531 records) occur after 1969, and the period with the largest number of outbreaks occurs in 1980-1984, with 1577 outbreaks. This 5 -year period shows an increase by over $300 \%$ compared to the previous period (19751979). The following period (1985-1989) shows the second largest number of outbreaks within the timeline chart, with 1060 outbreaks.

Figure 3 illustrates these changes on a finer scale. The maps indicate an increase in the number of plague outbreaks, and also, an increase in the spread of plague to other geographical parts of Sweden. In 1910-14, mainly the counties that surrounded Lake Mälaren (the lake where the crayfish plague was first discovered) reported crayfish plague. The crayfish plague spread gradually to other counties in Sweden, and by 1970, during the large-scale introduction of the signal crayfish, most of the counties in southern Sweden had crayfish plague in several waters. By 1980-84, the plague had reached the northern county of Gävleborg (county X), and most of the counties in the southern part of Sweden experienced very large numbers of outbreaks.

To ascertain whether the introduction of signal crayfish has had any effect on the plague outbreaks, two 20-year periods were compared, before and after the large-scale introduction in 1969. Figure 4 clearly shows that the later period has a larger number of plague outbreaks compared to the first period, for all except two counties, and that the difference in most cases is substantial. The difference between the two periods was significant ( $T=7 ; p=0.02$; Wilcoxon signed rank test). Since the second period showed a significantly larger number of outbreaks than the early period, our conclusion is that 


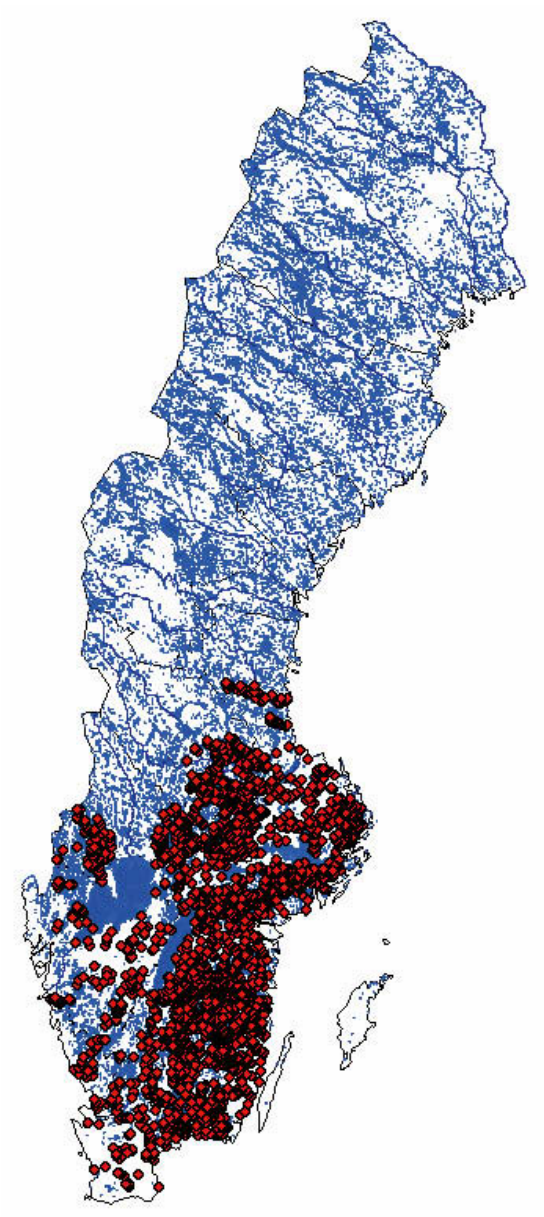

\section{Figure 1}

Records of plague outbreaks 1907-2004, taken from the Swedish Crayfish Plague Database. Dots indicate registered outbreaks, the blue background represents waters in Sweden.

\section{Figure 1}

Cas de peste enregistrés entre 1907 et 2004, d'après la base de données suédoise sur la peste des écrevisses. Les points localisent les cas de peste enregistrés, le fond bleu représente les eaux en Suède.

the introduction has had an effect on the spread of the crayfish plague, and that this has obviously affected the remaining noble crayfish populations negatively.

By studying the fisheries legislation during the large-scale introduction, we found that a more liberal legislation, towards issuing more licenses, accelerated the spread of signal crayfish into a large number of waters. During the period of the large-scale introduction of signal crayfish (1969-94), the fisheries legislation went from strict to liberal and back to strict again. In 1969, signal crayfish was introduced in 64 waters. At first, the fisheries legislation was quite strict, the earliest recommendations prescribed that the species were only to be introduced into waters where crayfish plague had occurred earlier, but not into waters where acute plague had been observed within the last 2 years, nature 


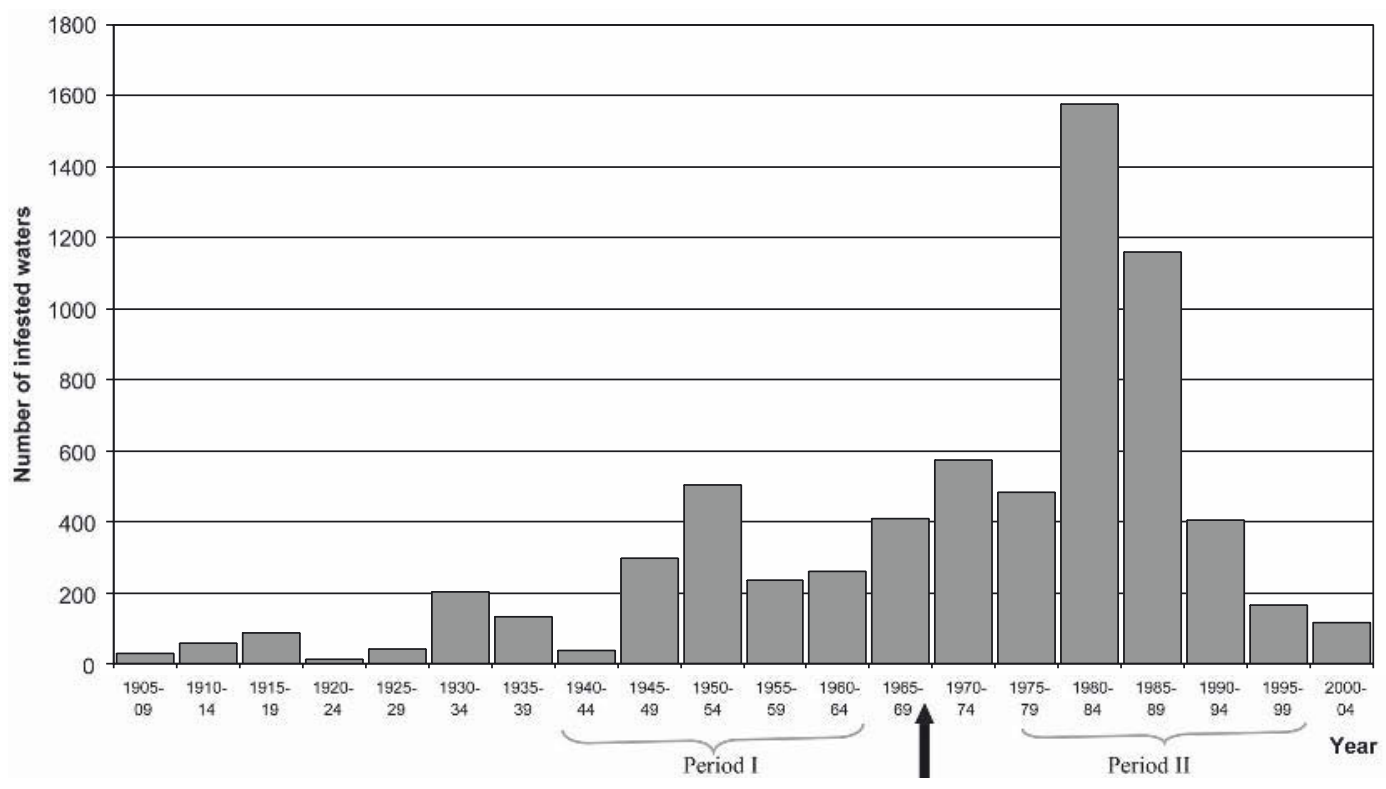

Figure 2

5-year period timeline chart of crayfish plague outbreaks in Sweden 1907-2004. Each bar represents the total number of crayfish plague outbreaks in Sweden, for a 5-year period. An arrow indicates when the large-scale introduction of signal crayfish occurred. The 2 periods (before and after the introduction) are used to analyse the effects of the introduction.

Figure 2

Représentation par tranches de 5 ans des cas peste des écrevisses relevés en Suède de 1907 à 2004. Chaque barre représente le nombre total de cas relevés en Suède sur une période de 5 ans. Une flèche indique la période d'introduction massive de l'écrevisse signal. Les deux périodes (avant et après l'introduction de l'écrevisse signal) sont celles utilisées pour analyser l'impact de cette introduction.

reserves, fish farms and not for farming purposes (i.e. ponds). From 1973, the watersheds on the Swedish West coast were protected from introductions of signal crayfish. Also, areas outside the natural distribution of noble crayfish, and watersheds holding viable populations of the noble crayfish, were protected. By 1976, a total number of 169 waters had been stocked with the signal crayfish. Gradually, the fisheries legislation became more liberal, and in 1978 stocking in ponds for farming was allowed. In 1983, signal crayfish had been stocked in 536 waters in Sweden (FJÄLLING \& FÜRST, 1985). In 1985, the islands of Gotland and Öland were closed while the ban on the Swedish West coast was abandoned. In 1988, waters holding non-harvestable populations of noble crayfish (less than one crayfish per trap and night) were opened for stocking, and this resulted in a remarkable increase in number of waters being stocked with signal crayfish. By 1989, it was estimated that 1000 waters was stocked with signal crayfish (WESTMAN et al., 1992) while a figure of 2200 was given in 1992 (FISKERIVERKET, 1993). This last figure included a total number of 1,380 farming licenses, mainly for pond culture. In 1994, the number of licenses for introduction of signal crayfish reached 3,000 (HÄGGSTRÖM 1994). Thus, in only 10 years (1983-1994) the licenses given increased with over 500\% (Figure 5). Later in 1994, the regulations were considerably sharpened since stocking was prohibited in watersheds lacking signal crayfish, and watersheds having stocks of noble crayfish. In 

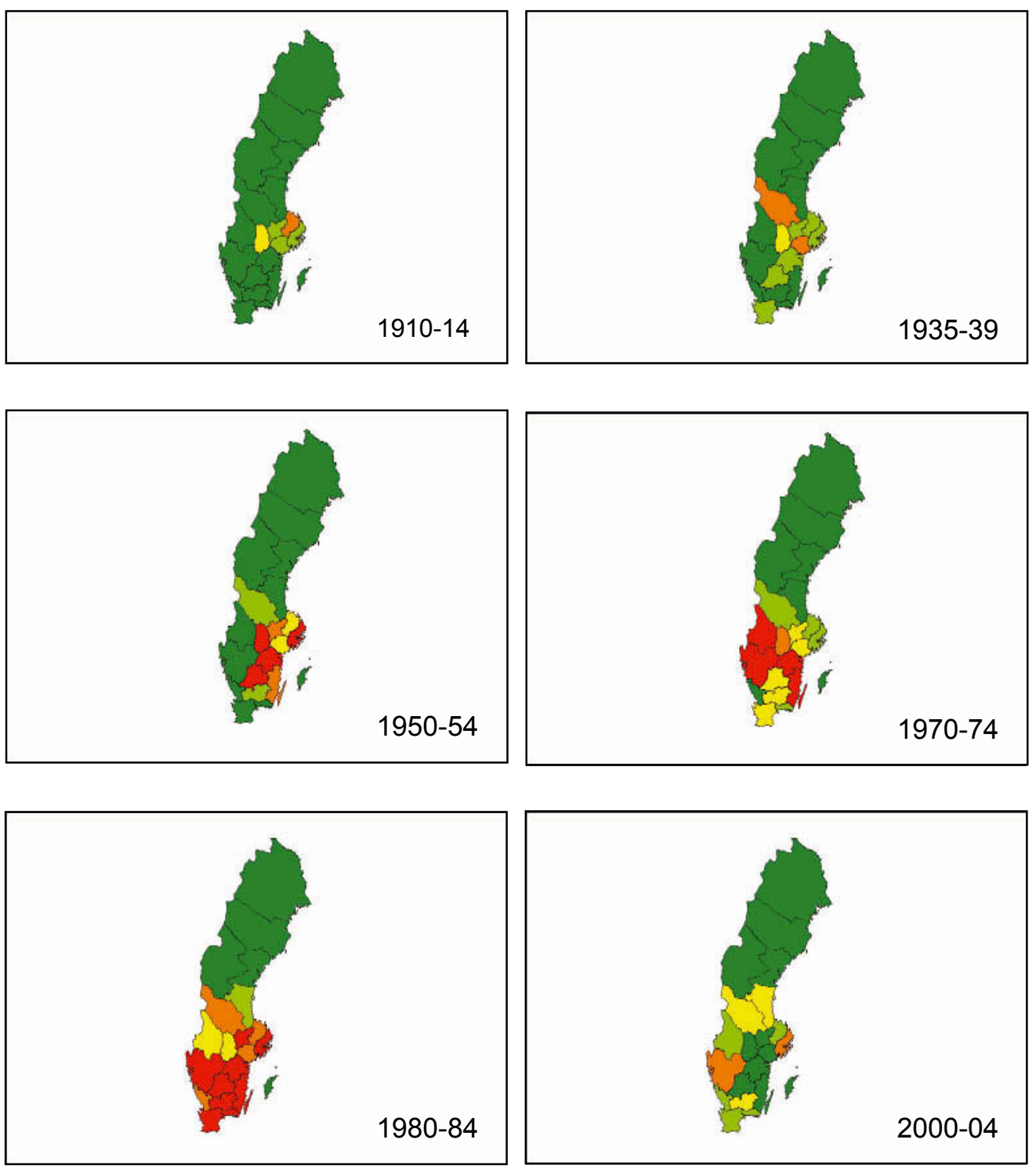

\begin{tabular}{|c|c|c|}
\hline \multirow{3}{*}{$\begin{array}{l}\text { Number of plague } \\
\text { outbreaks: }\end{array}$} & \multicolumn{2}{|c|}{50 to 400} \\
\hline & 25 to 4 & 49 \\
\hline & 10 to 2 & \\
\hline & 0 to & \\
\hline
\end{tabular}

Figure 3

Thematical maps over plague outbreaks in Sweden. Each county is coloured according to the number of outbreaks for a specific 5-year period. The northern part of Sweden has not reported any outbreaks of crayfish plague during 19072004 (dark green).

Figure 3

La peste des écrevisses en Suède. Chaque région est colorée en fonction du nombre de cas de peste relevés sur chaque période de 5 ans. II n'y a eu aucun cas de peste enregistré dans le Nord de la Suède de 1907 à 2004. 


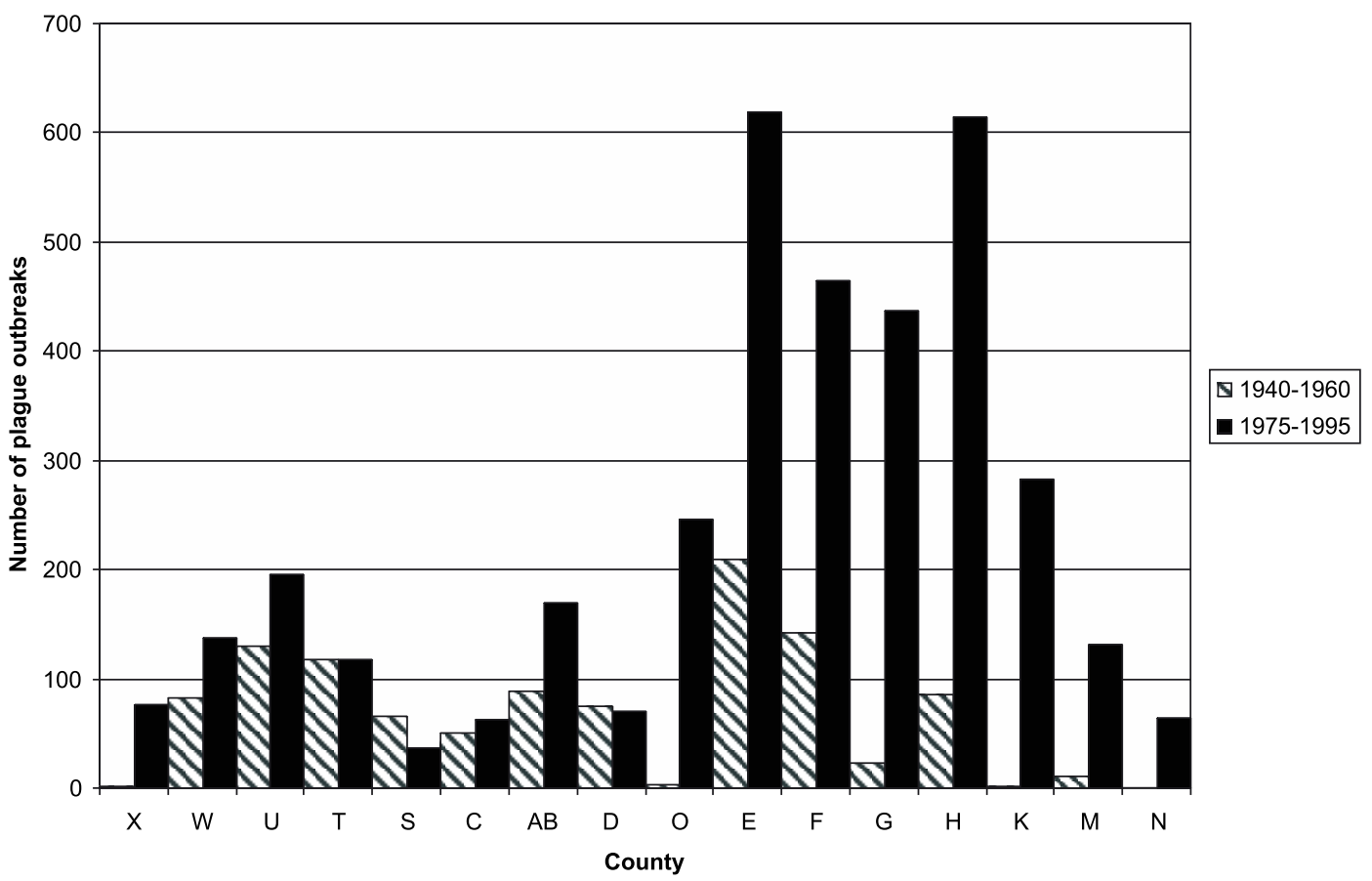

Figure 4

A comparison of crayfish plague outbreaks for each county (letters $X$ to $M$ ) during two periods, before (1940-60) and after (1975-94) the introduction of the signal crayfish in Sweden. The counties are arranged from north to south ( $X$ to $M)$. Only counties that have reported crayfish outbreaks are represented in the chart.

Figure 4

Comparaison des cas de peste de l'écrevisse enregistrés sur chaque " county " (lettres X à M) pendant deuX périodes, avant (1940-60) et après (1975-94) l'introduction de l'écrevisse signal en Suède. Les "counties" sont classés du Nord au Sud (X à $M)$. Seuls ont été retenus les " counties" où des cas de peste ont été enregistrés.

1997, there was only a slow increase in new waters stocked with signals and the total number was estimated to be a little more than 3000 (HÄGGSTRÖM 1997). In 2001, in addition to previous legislation, it was forbidden to stock signal crayfish in watersheds where no previous licenses had been given.

\section{DISCUSSION}

The development and spread of the crayfish plague in Sweden has been extensive since 1907. As time progresses (Figure 2), new regions in the country are affected (Figure 3). On a regional scale, the counties, having large number of plague outbreaks, are steadily increasing, which indicates an increased geographic spread of the disease. Consequently, as outbreaks of plague become more frequent, and widespread, particularly during 19801988 , the number of remaining noble populations decrease.

To display the increase after the large-scale introduction, two 20-year periods were compared (Figure 4). The results show that the second period has a significantly larger number of outbreaks than the early period, which indicates an increase in the number of outbreaks, due to the large-scale introduction. The number of outbreaks within the first 


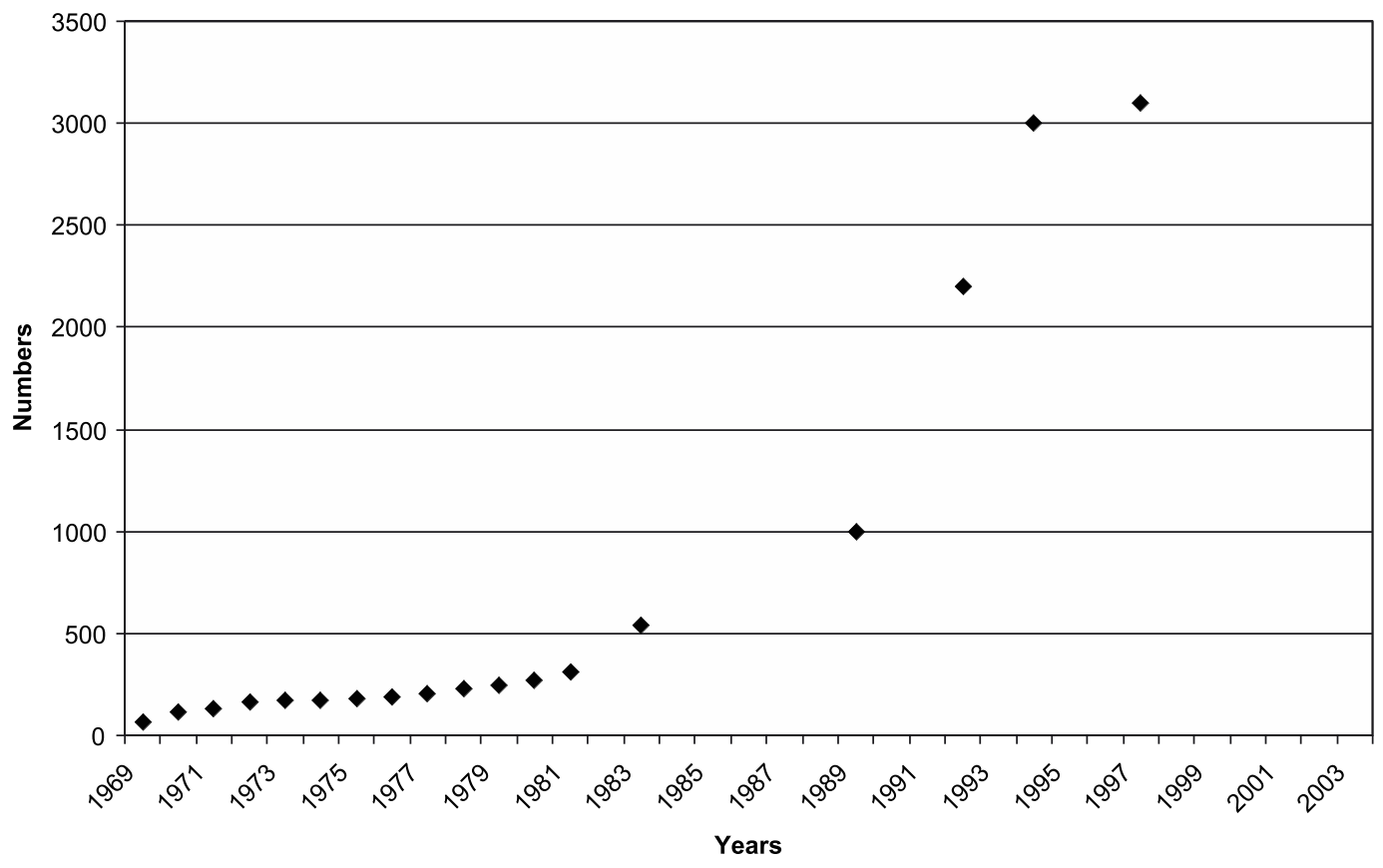

Figure 5

Numbers of licenses for stocking and culture of signal crayfish during the period 1969-2004. The number of licenses is accumulated, and reaches over 3000 licenses in 1997.

\section{Figure 5}

Nombre de permis de repeuplement et d'élevage de l'écrevisse signal delivers pendant la période 1969-2004. Le nombre de permis est cumulé et dépasse 3000 en 1997.

period (1940-1960) is obviously not affected by the introduction of signal crayfish at all, since the period ends the same year the first signal crayfish is introduced into Swedish waters (in lake Träsksjön, 1960). The second period (1975-1995) represents a time when it would be possible to detect the first impact in the form of mass mortalities, and noble crayfish decline, after the introduction of signal crayfish had taken place. During 19801984 , within the second period, the outbreaks reached nearly 1600, the largest number ever recorded (Figure 2). This represents almost 400 outbreaks of plague each year in Sweden.

It is important to point out that number of outbreaks is presented in absolute numbers. During the first period (1940-1960) there were at least 15000 remaining noble crayfish populations that could be infected (UNESTAM, 1969). Fewer noble crayfish populations could be infected during the second period (1975-1995), since the plague had already diminished the number of populations. Gradually, as the number of plague outbreaks increased, a lesser number of noble crayfish populations were left to be affected, but still the absolute number of outbreaks increased. When taking this fact into account, the negative effect of the introduction of signal crayfish on the noble crayfish populations is even more severe.

The changes in fisheries legislation are a reflection of how the policy to introduce signal crayfish changed the years during the introductions. The period with a more permissible legislation coincides with the fastest increase of issued stocking licences, obviously resulting in a fast increasing number of signal crayfish populations. From 1983- 
1994 the number of licenses increased with over 500\%. Furthermore, this coincides with the maximum number of recorded crayfish plague outbreaks ever (1,577 outbreaks 1980$85 ; 1,160$ outbreaks 1985-89) (Figure 2). In 1994, the noble crayfish populations had decreased to 1724 (FISKERIVERKET and NATURVÅRDSVERKET, 1998), which is only $6 \%$ of the original numbers from 1900, and the populations were still decreasing to reach approximately 1,000 in year 2002 (DATABASE OF CRAYFISH OCCURRENCES, 2005).

There is additional evidence for the importance of the signal crayfish, as a carrier and vector. There are four different genotypes of crayfish plague (HUANG et al, 1994). The genotype carried by the signal crayfish is responsible for all crayfish plague outbreaks in Sweden, that have been analysed since 1970 (SÖDERHÄLL and CERENIUS, 1999; SÖDERHÄLL, K., pers. comm.).

One important factor, which influences the rate of spread of signal crayfish with crayfish plague, is illegal introduction into new waters. With a larger number, and a wider spread, of the signal crayfish, illegal introductions of the species are facilitated (EDSMAN and SMIETANA, 2004, DIEGUEZ-URIBEONDO, this volume). Illegal introduction is not included in this study, but is one important agent for the spread of the crayfish plague to new areas. In fact, at present, illegal introductions is considered to be the most important cause for the continued spread of crayfish plague and the decline in noble crayfish populations in Sweden (FISKERIVERKET and NATURVÅRDSVERKET, 1998; EDSMAN, 2004).

\section{CONCLUSIONS}

One of the main reasons for the decline in noble crayfish populations in Sweden is the crayfish plague.

The signal crayfish, which is a chronic carrier of crayfish plague, was introduced in 1969 on a larger scale.

Signal crayfish populations have increased at a faster rate during the period of a more liberal legislation, when more stocking licenses were issued.

Crayfish plague outbreaks were more frequent during the period after the introduction of the signal crayfish, compared to the period before, despite there being fewer noble crayfish populations that could be infected in the later time period.

The introduction of the signal crayfish, due to a more permissible legislation, have accelerated the spread of crayfish plague to noble crayfish populations in the country and that is the main reason for the current decline of native crayfish populations

\section{ACKNOWLEDGEMENTS}

We would like to thank Herbert Wirlöf, Jan Fällgren, Mats Börje, Silja Hynynän, Tanja Martins who contributed to the preparation of the plague database, the fisheries officers at the Swedish County Administrations, who provided data, and two anonymous referees for helpful comments on the manuscript.

\section{REFERENCES}

ALDERMAN D.J., 1996. Geographical spread of bacterial and fungal diseases of crustaceans. Revue Scientifique et Technique Office International des Epizooties, 15(2), 603-632.

ALDERMAN D.J., POLGLASE J.L., 1988. Pathogens, parasites and commensals. Pp. 213-235 in: HOLDICH D.M., LOWERY, R.S. (eds.). Freshwater crayfish. Biology, management and exploitation. Croom Held Ltd, London. 
ALM G., 1929. Der Krebs und die Krebspest in Schweden. Zeitschribt für Fisherei, 27, 123-138. (In German).

ALM G., 1938. Kräftpestens spridning inom Sverige sommaren 1938. Svensk Fiskeritidskrift, 8, 203-205. (In Swedish).

ALM G., 1939. Kräftpestens utbredning inom Sverige sommaren 1939. SvenskFiskeritidskrift, 8, 201-202. (In Swedish).

ALM G., 1940. Kräftpestens utbredning inom Sverige sommaren 1940. SvenskFiskeritidskrift, s 190-191. (In Swedish).

ALM G., 1942. Kräftpestens utbredning inom Sverige sommaren 1942. SvenskFiskeritidskrift, 8, 153-154. (In Swedish).

ALM G., 1943. Kräftpestens utbredning inom Sverige sommaren 1943. Svensk Fiskeritidskrift, 8, 137-138. (In Swedish).

ALM G., 1944. Kräftpestens utbredning inom landet sommaren 1944. Svensk Fiskeritidskrift, 8, 129-130. (In Swedish).

ALM G., 1945. Kräftpestens utbredning inom landet sommaren 1945. Svensk Fiskeritidskrift, 9, 185-186. (In Swedish).

ALM G., 1946. Kräftpestens utbredning inom landet sommaren 1945. Svensk Fiskeritidskrift, s 181.(In Swedish).

ALM G., 1947. Kräftpestens utbredning inom landet sommaren 1947. Svensk Fiskeritidskrift, s 146-147. (In Swedish).

ALM G., 1948. Kräftpestens utbredning inom landet sommaren 1948. Svensk Fiskeritidskrift, s 123. (In Swedish).

ARWIDSSON I., 1920. Kräftpesten i Sverige. Anteckningar under åren 1909-1919. Meddelanden från Kungliga Lantbruksstyrelsen, 229 (126 p.). (In Swedish).

DAHR E., 1949. Kräftpestens utbredning år 1949. Svensk Fiskertidskrift, s 122-124. (In Swedish).

DATABASE OF CRAYFISH PLAGUE, 2005. Swedish Board of Fisheries, Institute of Freshwater Research (data available from author by request).

DATABASE OF CRAYFISH OCCURRENCES, 2005. Swedish Board of Fisheries, Institute of Freshwater Research (data available from author by request).

DIEGUEZ-URIBEONDO J., TEMINO C., MUZQUIZ J.L., 1997. The crayfish plague fungus (Aphanomyces astaci) in Spain. Bull. Fr. Pêche Piscic., 347, 753-763.

EDSMAN L., 2000. Crayfish conservation in Sweden, lessons to learn, p. 19-25. In: ROGERS D., BRICKLAND J. (Eds): Crayfish Conference Leeds. Environment agency Leeds.

EDSMAN L., 2004. The Swedish story about import of live crayfish. Bull. Fr. Pêche Piscic., 372-373, 281-288.

EDSMAN L., SMIETANA P., 2004. Exploitation, conservation, and legislation. Bull. Fr. Pêche Piscic., 372-373, 457-464.

EVANS L.H., EDGERTON B.F., 2002. Pathogens, parasites and commensals, p. 377-438. In: HOLDICH D.M. (Ed.). Biology of Freshwater Crayfish. Oxford, Ed. Blackwell Science, $654 \mathrm{p}$.

FISKERIVERKET, 1993. Ways of increasing populations of noble crayfish Astacus astacus in Swedish fresh waters. Information from the Institute of Freshwater Research. Drottningholm, 2, 1993, 66 p. (In Swedish with English summary). 
FISKERIVERKET and NATURVÅRDSVERKET, 1998, Action plan for the restoration of the noble crayfish in Sweden. JÄRVI T., THORELL L. (Eds), Fiskeriverket and Naturvårdsverket, Göteborg and Stockholm. 38 p. (In Swedish).

FJÄLLING A., FÜRST M., 1985. The introduction of the signal crayfish Pacifastacus leniusculus into Swedish waters: 1969-84. Information from the Institute of Freshwater Research, Drottningholm, 8, 1985, 29 p. (In Swedish with English summary).

HUANG T.S., CERENIUS L., SÖDERHÄLL K., 1994. Analysis of the genetic diversity in the crayfish plague fungus Aphanomyces astaci, by random amplification of polymorphic DNA. Aquaculture, 126, 1-10.

HÄGGSTRÖM Å., 1994. Report of the situation of the crayfish plague in Sweden 1994. Swedish Board of Fisheries, 7 p. (In Swedish).

HÄGGSTRÖM Å., 1997. Report of the situation of the crayfish plague in Sweden 1997. Swedish Board of Fisheries, 8 p. (In Swedish).

SKURDAL J., TUGBOL T., BURBA A., EDSMAN L., SÖDERBÄCK B., STYRISHAVE B., TUUSTI J., WESTMAN K., 1999. Crayfish introductions in the Nordic and Baltic countries. In: GHERARDI, F. and HOLDICH, D.M. (Eds.), Crayfish in Europe as alien species. How to make the best of a bad situation?, Balkema, Rotterdam, 193219.

SVÄRDSON G., 1965. The American crayfish Pacifastacus leniusculus Dana introduced into Sweden. Rep. Inst. Freshw. Res. Drottningholm, 46, 90-94.

SÖDERHÄLL K., CERENIUS L., 1999. The crayfish plague fungus: history and recent advances. Freshwater Crayfish, 12, 11-35.

UNESTAM T., 1969. Resistance to the crayfish plague in some American, Japanese and European crayfishes. Rep. Inst. Freshw. Res. Drottningholm, 49, 202-209.

UNESTAM T., 1972. On the host range and origin of the crayfish plague fungus. Rep. Inst. Freshw. Res. Drottningholm, 52, 199-203.

VALLIN S., 1928. Kräftpestens i Sverige under senaste år och vidtagna skyddsåtgärder. Ny svensk Fiskeritidskrift, 21, 154-155, 200-205. (In Swedish).

VALLIN S., 1930. Kräftpestens spridning inom Sverige under 1929-1930. Ny svensk Fiskeritidskrift, 15, 141-143. (In Swedish).

VALLIN S., 1931. Kräftpestens spridning inom Sverige under 1930-1931. Ny svensk Fiskeritidskrift, 15, 141-144. (In Swedish).

VALLIN S., 1933. Kräftpestens spridning inom Sverige under 1932-1933. Ny svensk Fiskeritidskrift, 15, 186-190. (In Swedish).

VALLIN S., 1934. Kräftpestens spridning inom Sverige under 1933-1934. Ny svensk Fikeritidskrift, 15, 169-172. (In Swedish).

VALLIN S., 1935. Kräftpestens spridning inom Sverige 1934-1935. Svensk Fiskeritidskrift, s 214-216. (In Swedish).

VALLIN S., 1936. Kräftpestens spridning inom Sverige 1935-1936. Svensk Fiskeritidskrift, 8, 199- 201. (In Swedish).

VALLIN S., 1937. Kräftpestens spridning inom Sverige 1936-1937. Svensk Fiskeritidskrift, s 226-227. (In Swedish).

WESTMAN K., ACKEFORS H. and NYLUND V., 1992. Kräftor - biologi, odling, fiske. Kiviksgårdens förlag. 152 p. (In Swedish). 